|Volume 6 |Number 1 |May 2021 |E-ISSN: 2503-4405 |P-ISSN: 2580-3441 |

\title{
The Leadership of Jean Valjean in Les Miserables Movie Directed by Tom Hooper
}

\author{
Tati Mardewi, Heydi Ruth Larashandy, Furi Indriyani, Nurmala Dewi \\ Universitas Bina Sarana Informatika \\ tati.tdi@bsi.ac.id,heydyruth31@gmail.com, furi.fin@bsi.ac.id, \\ nurmala.nmd@bsi.ac.id
}

\begin{abstract}
The objective of the research is to analyze the leadership that Jean Val jean showedin Les Miserables movie directed by Tom Hooper.This research focuses on what are the types and the impacts of the leaderships of Jean Val jean in Les Miserables.In this describtive qualitative study the writer collects the data from the scene and the conversation in the movie and material with a variety of resources such as books, journals, articles, and other references. After watching the movie repeatedly and collecting the data by pay attention to the conversation in the movie's scenes, the writer studies the whole story before continuing to the next step, then analyses the story is all about. The types of leadership that werefound in this movie are(1) Laissezfaire leadership and (2) Servant leadership. While there are threeimpacts of leadership that indeed to Jean Valjean as the main character in Les Miserables, namely(1)Inspiring confidence for others (2) Creating a respectful environment, and (3) Increasing loyalty and trust.This movie shows many things to be a good leader who can bring a big impact on people. We are all leaders in our lives. So, this movie gives us so many things that we can learn to have a better life.
\end{abstract}

Keyword: Leadership, Les Miserables, Literature

\section{Introduction}

Nowadays, a suitable leadership style is needed to respond to dynamic changes in every kind of environment. The leadership styles that chosen by leaders are going to give some impact on surroundings. Leaders deal with prominent challenges in adapting to a new leadership style and paradigms while leading workers from a variety of backgrounds. Leaders not only have an obvious order or plan but also have a suitable leadership style. In addition, the leadership of Jean Valjean in Les Miserables movie is going to be analyzed. The analysis is focused on the type and the impact of the leadership. The Les Miserables movie is one of the 
greatest pieces of literature that shown leadership. Literature goes to a beautiful purpose that has some kind of goal that aimed to entertain people no matter to the creator or the reader. The product of literature is not limited to the written text only, it also improves and becomes impressive when translated into other forms such as music and other forms. Literature also consists of value that gives us a moral review and some way to learn about other experiences in life."Literature is referred to as the entirety of written expression, with the restriction that not every written document can be categorized as literature in the more exact sense of the word"(Klarer, 2013). It meansthat the literature has large amounts of things, it can be written and unwritten forms. The things that are included in literature like a novel, fiction, nonfiction, novel, or autobiography. We can find pleasure, excitement, knowledge, personality, and other value in literature.

Since the movie is one of the most popular literary works or media or art forms that can convey information, messages or knowledge, ideas about various aspects of life or lifestyle of humans and the universe." The movie is also known as a film and is also one of the popular literary works that are useful for expressing thoughts, feelings, emotions, ideas, and so forth"(Madula et al.,2017). It means that movies can represent human artworks in visual and audio forms that are as media of communication and education.It can be defined that movies are parts of moving pictures containing shots and frames that give a window to "reality" and at the rear leave space for interpretations.

Some aspects that are consisted in a movie are character, plot, setting, theme, and point of view. The character is one of the aspects that is going to be described in this research."Characters are those who play a role in a story. Usually, personal identity or entity whose existence comes from fictional work or performance(Lapandja et al., 2016) say The character in a movie can be classified into two groups, major and minor characters. The major or main charactersplay an important role in the story or the novel. The minor characters are often called a supporter of the drama or the novel.They do not have an important role as major characters". The character is presented in a narrative work or drama, which by readers interpretedtohave certain moral qualities and tendencies as expressed in speech and action. The main character is the most important in a story, but it 
cannot be stood alone. Other characters are going to fill the flow of the story to be more convincing(AM et al., 2017). From the definition above, it can be concluded that the main character gives an essential role. But the main character also needs other roles such as the existence of the supporting roles for success, so the story can be more interesting and relatable because a movie without another character seems flat.In this research, the movie is analyzed is Les Miserables. The Les Miserables movieis a musical drama movie which was adapted from the novel Victor Hugo in 1862 and set in France. This movie is directed by Tom Hooper and starred by a talented actor, Hugh Jackman. In this movie, we can see the leadership from Jean Valjean as the main character. Leadership is the most extensively studied social influence process in behavioral science, particularly in the management literature(VanMeter et al., 2016).There are many types of leadership, and two of them are laissez-faire leadership and servant leadership. Laissez-faire leadership is a style of leadership in which leaders are hands in hands and enable members of the group to make decisions(Cherry, 2019).Laissez-faire leaders were arguednot to invest in the advancement of workers becausethey believe that employees can take care ofthemselves, Puni asserted in (Jony, Mohammad. Alam, 2019). So, it can be concluded that laissez-faire leadership shows an attitude of trust and reliance on their employees. The leaders of this type do not manage and involve with detail but they let their employees use their creativity, resources, and experience to help them meet their purposes. Another type of leadership that is discussed in this research is servant leadership. Servant leadership has been recognized as a leadership philosophy addressing the concerns of ethics(Carter, D., \& Baghurst, 2014). Servant leadership most closely illustrates participative leadership. Itattracts employee trust, which can make credible improvements in an organization.Servant leadership is characterized by two key factors: a primary motivation of servingthrough leading and a priority interest in employee wellbeing(VanMeter et al., 2016). With servant leadership being a people-oriented approach, which prioritizes support for employees, it is projected to yield employees with a greater commitment to the organization in exchange for the support and empowerment from the organization, asrepresented by the servant leader (Asag-Gau \& Dierendonck, 2011). These types of leadership are shown in Les Miserables movie. The movietellsabout Jean Valjean's redemption after stealing 
a loaf of bread and struggles to suffer in France. Jean Valjean is released from prison and promises to become an honest man and mask his identity. Finally, he becomes the town's mayor.

\section{Research Methods}

In this analysis, the writer uses the descriptive qualitative method. Descriptive qualitative research is intended to describe the existedphenomena that are natural or human engineering(Sukmadinata, 2011). It pays more attention to the characteristic, quality, and activity interrelationship. The procedure of the analysis has some steps. The writer collects the data from the scene and the conversation in the movie and material with a variety of resources such as books, journals, articles, and other references. The primary resources of this research are from the movie itself, the Les Miserables movie directed by Tom Hooper. After watching the movie repeatedly and collecting the data by pay attention to the conversation in the movie's scenes, the writer studies the wholestory before continuing to the next step, then analyses the story is all about,including the types and the impacts of the leaderships of Jean Valjean that the writer can take from themovie.

The main source of this research is the Les Miserables movie. The writer collectsthe data by watching the movie repeatedly to getting phrases or sentences in the movie scenes that support the research purpose. The data can be in phrases or sentence forms. After collecting the data, the writer uses the following steps for analyzing:

1. Data reduction

This step involves selecting, focusing, condensing, and transforming data. The process should be guided by thinking about which data best answer the evaluation questions.

2. Data display

This involves creating an organized, compressed way of arranging data (such as through a diagram, chart, matrix, or text). The display should help facilitate identifying themes, patterns, and connections that help answer your evaluation questions. This step usually involves coding, 
where you mark passages of text (or parts of images or sections of a video, etc.) that have the same message or are connected in some way, and you write an accompanying explanation of what the selected passages have in common.

3. Drawing conclusion

During this last step, revisit the data many times to verify, test, or confirm the themes and patterns you have identified.

\section{Research Finding and Discussion}

\subsection{Research Finding}

After collecting the data that are in phrases or sentence forms from theLes Miserablesmovie directed by Tom Hooper, the writer uses there three steps to analyze the data, data reduction, data display, and conclusion.

\section{Data reduction}

\begin{tabular}{|c|c|}
\hline Laissez-faire Leadership & $\begin{array}{l}\text { finish these,foreman, make them calm and } \\
\text { patient }\end{array}$ \\
\hline Servant Leadership & Valjean: hold on it \\
\hline Inspiringconfidenceforothers & $\begin{array}{l}\text { I'm here to save cosset, I will pay for all of } \\
\text { his debt. To take cosset to go, there is a } \\
\text { duty I have made, because I had blind for } \\
\text { one who needs me, now your mother is } \\
\text { safe with God! And I stand here for her } \\
\text { place, from now and cosset will be in my } \\
\text { protection. Cosset have a father now." }\end{array}$ \\
\hline Creating a Respectful Environment & Welcome, sir! The lawenforcement \\
\hline Creating a respectful environment & $\begin{array}{l}\text { Is that true what I have done? to a woman } \\
\text { who lost a soul, in the name of my task, it } \\
\text { has just begun, I'm taking this woman to } \\
\text { the hospital }\end{array}$ \\
\hline
\end{tabular}




\section{Data display and conclusion}

Laissez-faire Leadership

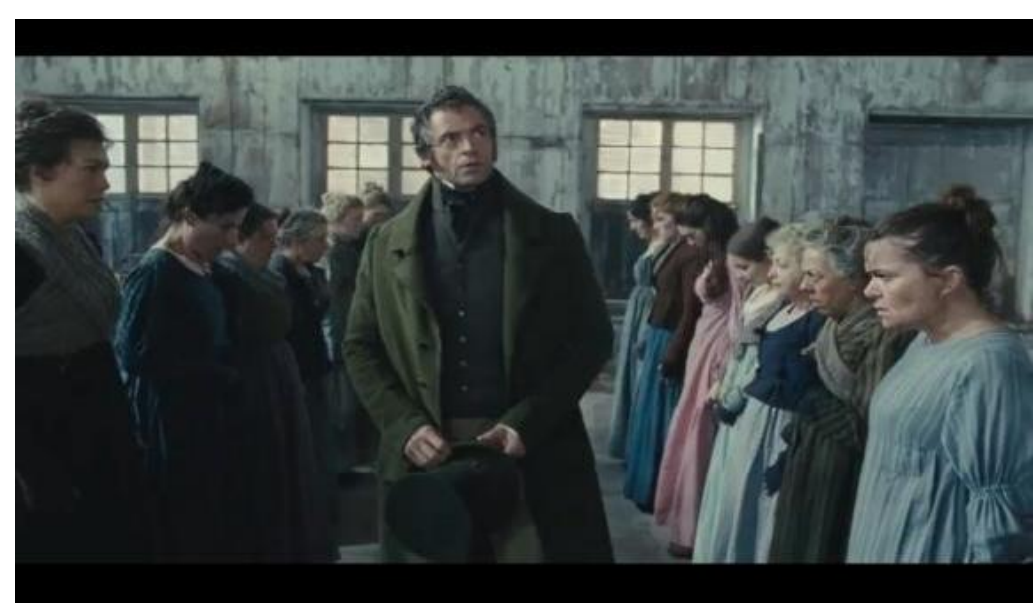

Source: Les Miserables movie

Figure III. 1

Valjean asked the foreman to handle the problem.

JeanValjean: " finish these, foreman. make them calm and patient"

Foreman: "yes, sir"

(Jean Valjean's Office - Min 17: 00: 00)

From this scene we can see point one as a Leader Jean Valjean has another work that he must do, he must welcome the inspector from French. so he asks the foreman to handle the problem among the worker, as a leader he trusts his worker to handle a problem. We can see that Valjean give trust and Jean Valjean let his employee assume responsibility in making a decision 


\section{Servant Leadership}

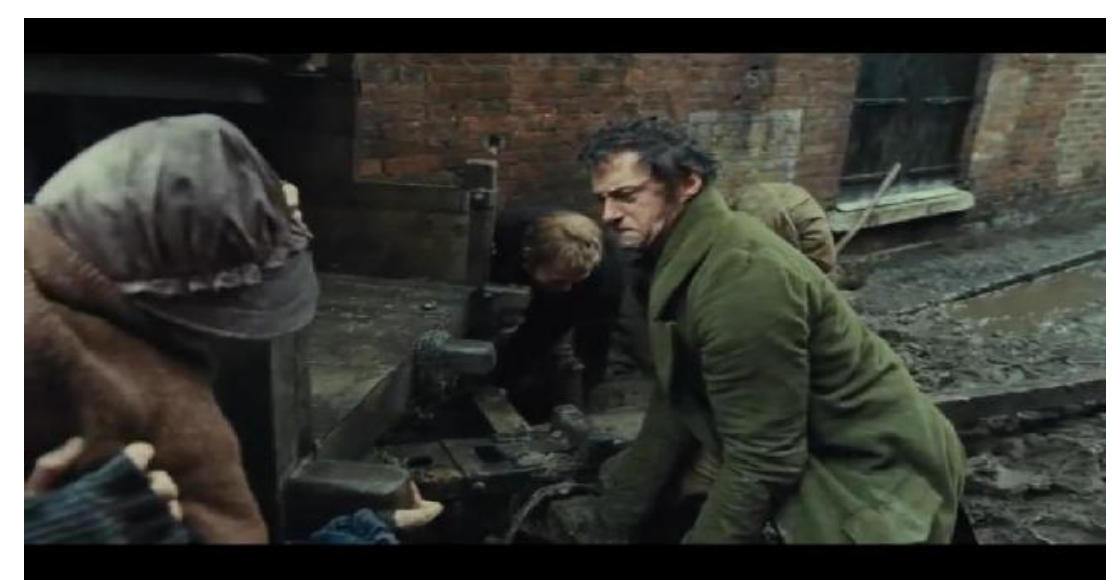

Source: Les Miserables movie

Figure III.2

Valjean is helping the old man

Valjean: hold on it (Valjean took the old man away from the cart)

(The street - Min 21:20: 00)

From the scene above it can be explained that Jean Valjean is helping the old man, it is mean he can relate well to his people with low-profile and very welcome to down earth also his people trust him and depend on him. From all the scenes above we can conclude that Jean Valjean has a good character of leadership and he is a servant to his people in a good way. From his ability to treat people he can achieve his success as a mayor of Montreuil- Suer-Mer. 
Inspiring confidence for others.

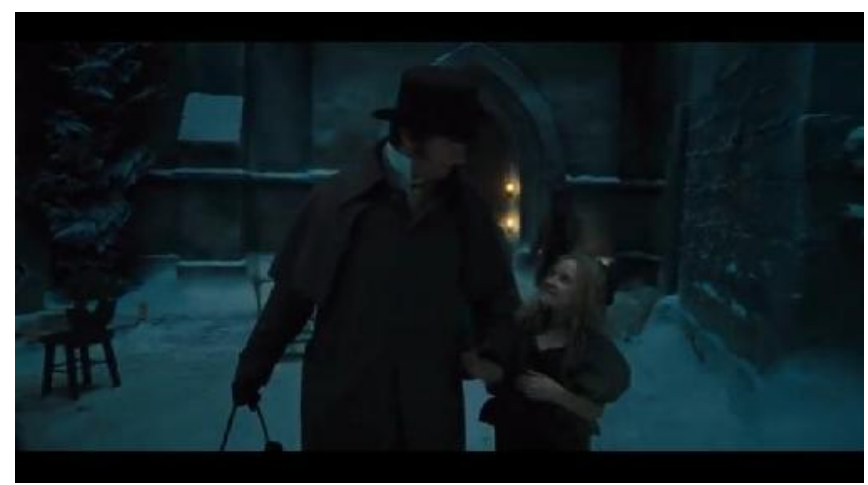

Source: Les Miserables movie

Figure III.3

Jean Valjean Comes to bring cosset go.

Jean Valjean: "I'm here to save cosset, I will pay for all of his debt. To take cosset to go, there is a duty I have made, because I had blind for one who needs me, now your mother is safe with God! And I stand here for her place, from now and cosset will be in my protection. Cosset have a father now."

(The lodging - Min 54: 00)

This scene shows that Jean Valjean is paying all of his debt to the owner of the lodging. Jean Valjean being cosset father also a mom. Valjean promises will bring cossetwhereverhegoes. Cosset has lived with people that make her life in a bad situation that destroy her self-esteem and confidence.

From this scene can be concluded that Jean Val jean gives hope and inspires Cosset to be confident to face life. 


\section{Creating a Respectful Environment}

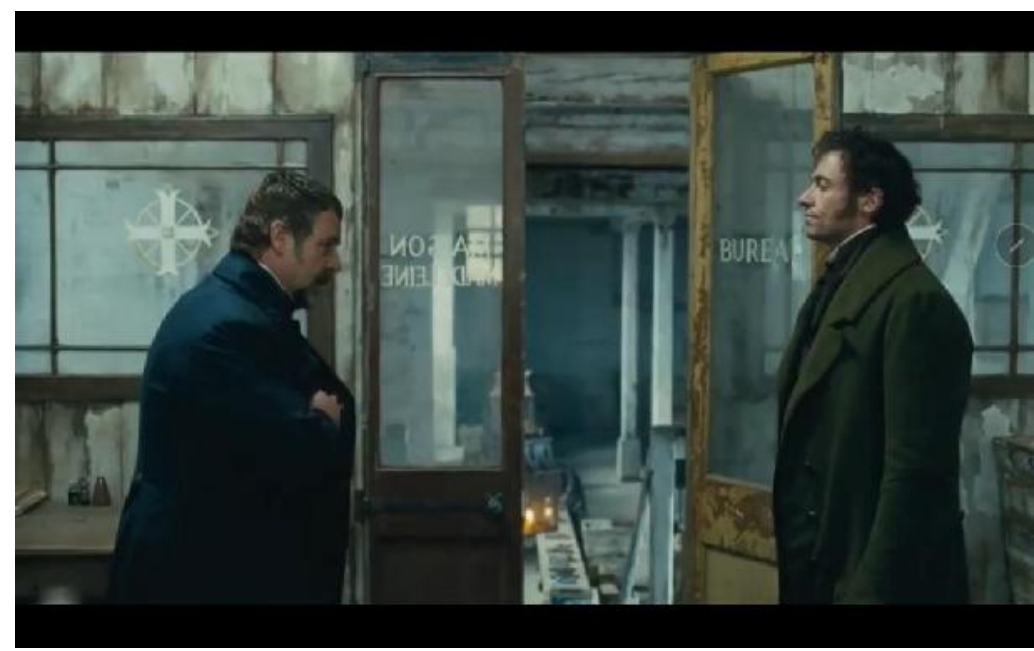

Source: Les Miserables Movie

Figure III.4

Valjean is welcoming the inspector

JeanValjean: “WelcomeInspector!”

Javert: "Please call me Javert. I am here ready to serve you with justice and law in ourhands."

JeanValjean: Welcome,sir! The lawenforcement.

Javert: "You are the pride of the city, you are praised by the nobles, your success has been rewarded, with the best shipment from French, your citizensthrive."

00)

(Jean Valjean's Office - Min. 20: 00:

From the conversation above it can be explained that Jean Valjean is welcoming the best inspector in French. He is welcoming the inspector with much pleasure and respect, so the inspector responds to Jean Valjean with respect too. It is meant that Valjean acts and serves well as the government messenger and be known as a good mayor. There is something implied in this situation that Jean Valjean does to 
the inspector but it is only a trick to create a respectful environment for his workers.

Increasing Loyalty and Trust

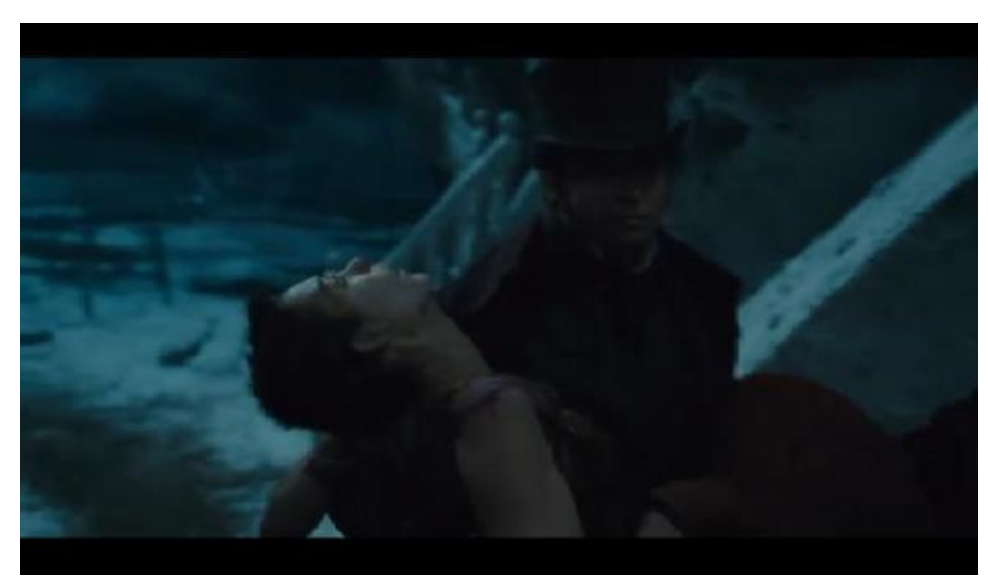

Source: Les Miserables Movie

Figure III.5

Valjean saved the woman that gets fired by his foreman from a prostitution place.

Thewoman: “sir please don't mock me now, it's enough I lost my pride, you let your foreman fired me away, yes you were there and turn aside."

JeanValjean: "Is that true what I have done? to a woman who lost a soul, in the name of my task, it has just begun, I'm taking this woman to the hospital"

(Prostitution place - Min 35: 00: 00)

The scene above tells that Valjean saved Fatine from the inspector that will bringhertothejailand bringFatinetohospitalaftersoldhisteeth,hair, andbodyto pay for his daughter's life. Valjean promises to Fatine to takes care of his daughter, Cosset. From this scene we can see that Valjean likes to servant others, he does not like to see someone who treats others badly and makes Fatine feel comfortable and safe with him. 


\subsection{Discussion}

This research has shown that the types and the impacts of leadership in the Les Miserablesmovie. Two types of leadership that are found are Laissez-faire leadership and Servant leadership.The impactsareconsisted of inspiringconfidenceforothers, creating a respectful environment, and increasing loyalty and trust.

Laissez-faire leadershiphas a hands-off approach and lets their employees assume responsibility in the decision-making process, although they must still set employee expectations and monitor performance. This leadership style can be effective when working with highly experienced and confidentemployees. One of the scenes that are proved Laissez-faire leadership iswhen Valjean asked the foreman to handle the problem in the factory and let his employee decide on the problem that happened insight the factory. Valjean believed by doing this the situation becomes much better because the foreman knew all about the workers in the factory.

The servant leadership principle is a "servant first". It means leaders focus on the needs of others, especially team members before considering their own. This leadership style can be effective for humanitarian organizations, nonprofits, and teams that need to create diversity, inclusion, andmorale. In this type of leadership, the writer finds four scenes that shown this type of leadership. It is proved when Valjean is helping the oldman, without having doubt, he goes straight ahead help the worker even he has an important guest who helps to goal his business.

Inspiringconfidenceforothers means a leader who minimizes uncertainty and supports the belief that there is a future in what they are doing will be able to drive higher levels of engagement and affects others around him to be confident as well. In this impact of leadership, the writer finds five scenes that shown this impact. It is proved when Jean Valjean who is a leader not only builds confidence in his workers but also to Cosset, Fatine's daughter. Cosset who lived with a bad couple took bad treatment that makes her lonely and unconfident. Jean Valjean builds others' confidence by inspiring them with their belief and hope. 
Creating a respectful environment means a leader who recognizes his employee is a key in creating a respectful environment. People like to be appreciated, acknowledged, and respected. Thus, giving the impact in raising their morale. In this impact of leadership, the writer finds four scenes that shown this impact. It is proved when Jean Valjean welcomes a government messenger who wanted to inspect and check his workers rudely, but Jean Valjean gave his respect to the messenger first to show that all his workers had to be respected too. So, the messenger had to do the inspection and checking an inappropriate way.

Increasing loyalty and trust means a leader who demonstrates genuine concern towards their partner will impact in the raise of their loyalty towards the cause and the leader, and also raise their trust towards the cause and of their leader. This will also raise the engagement level and thus, raise the overall quality of the human resource, and productivity. In this impact of leadership, the writer finds three scenes that shown this impact. It is proved when Jean Valjeansaved one of his workers from a prostitution place. The worker was in a hopeless situation, but Jean Valjean kept helping her. He never gave up to fire his worker's life and hopes that makes the worker trust him.

\section{CONCLUSION AND SUGGESTION}

In this research,the writer found two types and three impacts of leadership. The types of leadership are laissez-faire leadership and servant leadership. The impact of leadership is inspiringconfidenceforothers, creating a respectful environment, and increasing loyalty and trust. Laissez-faire leadership is shown inthis movie when Jean Valjean lets his foreman for handle the problem in the factory and also his employee decides for the problem that happened insight the factory. Servant leadership is shown in this movie when Jean Valjean is helping the oldman, without having a doubt. Inspiringconfidenceforothers is shown in this movie when Jean Valjean who is a leader not only builds confidence in his workers but also to Cosset, Fatine daughter. Creating a respectful environment is shown in this movie when Jean Valjean welcomes a government messenger who wanted to inspect and check his workers rudely, but Jean Valjean gave his respect to the messenger first to show that all his workers had to be respected too. The last is increasing loyalty and trust, which is shown in this movie when Jean Valjean saved 98 | ENGLISH EDUCATION Journal Of English Teaching and Research 
one of his workers from a prostitution place. For the suggestion, the writer would like to convey how important leadership is in our lives and give some suggestionsas follows. For next researchers, if they are doing research on leadershipand its impact, the researchers should explain more about it. In another word, the researchers have to comprehend more what leadership and the impact are in the broadest sense. The writer hopesthat this article can help the next researcher who wants to take the same topic.For readers, the writer hopes this article can help them in understanding the meaning of leadership that has been described by the researcher in this paper and it can be a benchmark or reference and reading that educate and inform the readers who still confuse about what leadership is.

\section{References}

Almaki, S. H., Silong, A. D., Idris, K., \& Abd. Wahat, N. W. (2016). Understanding of the Meaning of Leadership from the Perspective of Muslim Women Academic Leaders. Journal of Educational and Social Research. https://doi.org/10.5901/jesr.2016.v6n2p225

AM, Y., Kuncara, S., \& Setyowati, R. (2017). Analysis of the Main Character Needs in Life of Pi Movie Using Maslow's Theory. Ilmu Budaya.

Asag-Gau, L., \& Dierendonck, D. Van. (2011). The impact of servant leadership on organizational commitment among the highly talented: The role of challenging work conditions and psychological empowerment. European Journal of International Management. https://doi.org/10.1504/EJIM.2011.042174

Carter, D., \& Baghurst, T. (2014). The influence of servant leadership on restaurant employee engagement. Journal of Business Ethics, 124(3), 453-464.

Cherry, K. (2019). Autocratic Leadership Key Characteristics, Strengths, and Weaknesses of Autocratic Leadership.

Jony, Mohammad. Alam, M. J. M. (2019). The Impact of Autocratic, Democratic and Laissez-Faire Leadership Styles on the Success of the Organization: A Study on the Different Popular Restaurants of Mymensingh, Bangladesh. Canadian Journal of Business and Information Studies. https://doi.org/10.34104/cjbis.019.028038 
Klarer, M. (2013). An introduction to literary studies. In An Introduction to Literary Studies. https://doi.org/10.4324/9780203068915

Lapandja, F. K. ., Usman, S., \& M. (2016). A Study of Main Character And Plot. EJournal of English Language Teaching Society, 4(1), 1-13.

Madula, J., Kuncara, S. D., \& Asanti, C. (2017). Rebellion Against Racism and Discrimination in the Movies Rise of the Planet of the Apes and Dawn of the Planet of the Apes. 1.

Sukmadinata, N. . (2011). Metode Penelitian Pendidikan. PT Remaja Rosdakarya.

VanMeter, R., Chonko, L. B., Grisaffe, D. B., \& Goad, E. A. (2016). In search of clarity on servant leadership: domain specification and reconceptualization. AMS Review. https://doi.org/10.1007/s13162-016-0075-2 